University for Business and Technology in Kosovo

UBT Knowledge Center

UBT International Conference

2015 UBT International Conference

Nov 7th, 9:00 AM - 5:00 PM

\title{
How does a small business in Russia play its economic role?
}

Liudmila Guzikova

Peter the Great Saint-Petersburg Polytechnic University, guzikova@mail.ru

Follow this and additional works at: https://knowledgecenter.ubt-uni.net/conference

Part of the Business Commons

\section{Recommended Citation}

Guzikova, Liudmila, "How does a small business in Russia play its economic role?" (2015). UBT

International Conference. 21.

https://knowledgecenter.ubt-uni.net/conference/2015/all-events/21

This Event is brought to you for free and open access by the Publication and Journals at UBT Knowledge Center. It has been accepted for inclusion in UBT International Conference by an authorized administrator of UBT Knowledge Center. For more information, please contact knowledge.center@ubt-uni.net. 


\title{
How does a small business in Russia play its economic role?
}

\author{
Liudmila Guzikova \\ Peter the Great Saint-Petersburg Polytechnic University, Polytekhnicheskaya 29, \\ 195251, Saint-Petersburg, Russia \\ guzikova@mail.ru
}

\begin{abstract}
Small business is an integral part of the market economy. The main economic functions usually attributed to small businesses are the following: innovation, combating monopolies and maintain a competitive environment, combating unemployment and creating jobs, increasing income of the general population and, consequently, the expansion of consumer demand, increase the professional activity, the development of entrepreneurial skills, spirit, and traditions as an important institution of civil society, the formation of the middle class as a basis for socio-political stability of the state.The goal of research - on the basis of statistical and factual information to assess the extent to which a small business in nowdays.

Russia carries out these functions, and identify the factors that promote and prevent their implementation.
\end{abstract}

Keywords: small business, entrepreneurship, innovation, competitive environment, income in small businesses

\section{Introduction}

Small business is an integral and significant part of the market economy. Among the main functions small business should perform the following are usually mentioned: innovation, anti-monopolism and maintenance of a market competition, combating unemployment and creating jobs, increasing income of population and, consequently, the expansion of consumer demand, increase of professional activity, development of entrepreneurial skills, spirit and traditions as an important institution of civil society, formation of the middle class as a basis for socio-political stability of the state. In Russia economic entities are considered as small enterprises in accordance with the criteria established by the Federal Law of July 24, 2007 №209-FZ "On the development of small and medium enterprises in the Russian Federation." According to the Federal Low, 2007 the following criteria are to be taken into account: governmental participation in the equity of legal entity, average number of employees; revenue from sale of goods (works, services), excluding value-added tax. The problem of small business development has become one of the most popular areas of study for the Russian researchers in the 1990s, when the market reforms started and many people believed that the small business will be a source of wealth and prosperity to them personally and to the society as the whole. This opinion consolidated academic researchers and practitioners-entrepreneurs, so that the activities of the latter provided empirical material for the first. Current paper is an attempt to analyze small business in Russia in terms of its economic functions.

The study exploits the data of Federal statistics of Russian Federation available on www.gks.ru as the base of calculations and conclusions.

\section{Main positions and results}

The support for small business is declared in Russia as one of the state policy priorities. Both federal and regional foundations were established for financial and credit support of small business. These foundations can act as direct lenders and as guarantors of entrepreneurs. The government has developed a number of programs to promote small businesses aimed at helping them to adapt to 
market conditions. State assists small businesses in the new jobs creation, provides information and consulting.

However, the average efficiency of small business as a taxpayer is two times lower than the efficiency of large business, and the costs of maintaining the apparatus of officials engaged in the implementation of relevant programs are quite high. Critics argue that the support for small business is, in fact, a form of social protection. [1]

According to the polls only $3-4 \%$ of the respondents indicate that they are doing business. Proportion of respondents wishing to have their own business was $20 \%$ (among the young - $40 \%$ ), however, only $10 \%$ of those polled said they were going to start their own business in the nearest future. [2]

There are three theoretical models to explain the quantitative growth and qualitative development of small businesses:

model of economic recession which considers unemployment as a factor contributing to the growth of small enterprises;

model of income growth representing the increase in the number of small businesses as a response to increased demand;

model explaining the surge in the creation of new firms by development of new technologies. [3]

It is worth to mention that the number of the small enterprises in Russia has significantly negative correlation both with the level of unemployment and average income per capita.

Since 2010 to 2013 the total number of small enterprises in Russia increased by $26 \%$ - from 1,644,300 to $2,063,100$. The share of micro-enterprises has increased during this period from $86.07 \%$ to $88.63 \%$, that is, the vast majority of small businesses have no more than 15 employees and the annual revenue less than 60 million rubles (approximately 800,000 euro on 10.09.2015).

The further analysis shows how the small business in Russia performs the main functions characteristic for this kind economic activity.

\subsection{Innovation}

The following data allows us to understand the role of small businesses in the innovation and the nature of the innovation in the small innovation-oriented industrial enterprises.

In 2013 the total expenditures on technological innovation made by enterprises of the extractive and manufacturing industry, electricity, gas and water production and distribution amounted to 13.2061 billion rub. The share of small manufacturing enterprises engaged in innovation constituted $5.1 \%$, the volume of revenue from sales of innovative products was equal to 26.2692 billion rubles, but the proportion of revenue from innovative products to total revenues was equal to only $2.24 \%$.

The above indicators do not currently allow consideration a small business as innovative element of the Russian economy.

The following data allows understanding the role of small business in the innovation and the nature of the innovation in the small innovation-oriented industrial enterprises.

According to Federal Statistics the largest share among small businesses belongs to trade and repair of motor vehicles and household goods (more than 31\%), followed by real estate transactions and construction, whose total share is more than $30 \%$.

In the cost structure on technological innovation of small manufacturing enterprises more than $40 \%$ constituted the expenses for machinery and equipment purchase. On the research and development of new products, services and methods of production (transfer), new production processes were spent more than $30 \%$ of the total technological innovation costs. Purchase of technologies and software takes about $3 \%$, and personnel training as well as marketing research take less than $1 \%$ each. It should be mentioned that subsidizing of the costs on innovation is one of the main directions of governmental support. Currently, the Russian small business does not perform the basic functions of the diversification of production and implementation of effective and innovative projects, and only acts as an intermediary between the producer (as a rule, foreign) and domestic consumers. Small business is developing in the sphere of a rapid turnover of capital and does not participate in the scientific research. [4]

The reduction of the role of small business to mediating and to promoting of foreign products will inevitably lead to a drop of the real sector of the economy, to the loss of competitive advantages, to a slowdown in the development of the scientific sector and the ultimate loss of communication between the industrial and scientific sectors. 


\subsection{Anti-monopoly and competition}

The revenue of small enterprises in 2013 amounted to $20.5 \%$ of total revenue in economy. At the same time the share of small businesses in capital and current assets were equal respectively to $40.6 \%$ and $39.1 \%$ of the corresponding aggregate indicators of the Russian economy. In turn, the revenue of the processing small businesses amounted to only $9.4 \%$ of the total revenue of small businesses. The comparison of the revenue and the assets proportions leads to the conclusion that small business activity is lower compared to that of the large business, and it is manifested in a slower turnover of assets. Thus, the statistics do not allow saying that small business across the country is able to counteract monopolistic and significantly affect the competitive situation. This should not exclude the possibility of competition between local small businesses in niche markets not interesting for large business.

\subsection{Job creation and unemployment combat}

Since 2010 to 2013 the average number of small businesses employees has increased from 9,790.2 thousand to $10,775.2$ thousand, and constituted a little more than $14 \%$ of the average number of economically active population and in comparison with 2010 the share of employment in small the business has grown by about $1.2 \%$, while the average employment rate increased by $2.1 \%$.

The value of the average number of employees per one enterprise amounted to 5.22. On the one hand, this is a consequence of the high proportion of micro businesses and reflects the rather small size of most small businesses, and on the other hand, this confirms the wide practice of involving employees without formal registration.

Thus, small business plays a noticeable but not decisive role in providing employment in Russia.

\subsection{Impact on income}

Dynamics of average monthly wages of small businesses employees in shown in Table 1.

In our opinion, it is quite obvious that the income, significantly less than the average per capita income, which purchasing power, in turn, is significantly less than the purchasing power of average per capita income in developed countries, can't be an attractive factor for involvement in small business. This is especially true for small businesses in the manufacturing sector, where wages are below the average for small businesses.

We can conclude that for a large part of employees their employment in small business is forced due to the lack of employment opportunities in large enterprises of the private and public sectors, and the significant motive for participation in small business is the threat of unemployment and the complete loss of income.

Table 1. Wages in small business

\begin{tabular}{|l|c|c|c|c|}
\hline \multicolumn{1}{|c|}{ Indicator } & 2010 & 2011 & 2012 & 2013 \\
\hline $\begin{array}{l}\text { Average monthly wage of small business } \\
\text { employee, rub. }\end{array}$ & 12367 & 15743 & 16711 & 17948 \\
\hline $\begin{array}{l}\text { Ratio of small business average wage to } \\
\text { average income per capita }\end{array}$ & 0,732 & 0,830 & 0,804 & 0,773 \\
\hline $\begin{array}{l}\text { Average monthly wage of micro-enterprises } \\
\text { employee, rub. }\end{array}$ & 10612 & 12855 & 13898 & 15039 \\
\hline $\begin{array}{l}\text { Ratio of the average micro-enterprise } \\
\text { employee monthly wage to average income } \\
\text { per capita }\end{array}$ & 0,628 & 0,678 & 0,669 & 0,648 \\
\hline $\begin{array}{l}\text { Average monthly wage of small } \\
\text { manufacturing business employee, rub. }\end{array}$ & 11581 & 13822 & 15243 & 16807 \\
\hline $\begin{array}{l}\text { Ratio of the average monthly wage of small } \\
\text { manufacturing business employee to the } \\
\text { average wage for small businesses }\end{array}$ & 0,936 & 0,878 & 0,912 & 0,936 \\
\hline
\end{tabular}


In accordance with economic theory entrepreneurship must be repaid above the average level, as otherwise the entrepreneur does not receive compensation for the higher level of accepted risk [5]. In the situation illustrated above, incentives for the development of entrepreneurship and risk-taking are absent.

\subsection{Economic productivity}

In 2013 the share of profitable small enterprises was equal to $80.5 \%$, and for small enterprises of manufacturing industries $-80.0 \%$.

The net financial result amounted to small enterprises Russia 1,437,052 m rubles and in comparison with the previous year increased by $7.7 \%$. The net financial result of microenterprises amounted to $849,883 \mathrm{~m}$ rubles and in comparison with the previous year increased by $48.6 \%$. The corresponding indicators for the small businesses of manufacturing sector were as follows: profit constituted 130,387 m. rubles $(18.8 \%)$, profit of microbusiness constituted $56,733 \mathrm{~m}$ rubles $(+53.8 \%)$. Thus, manufacturing in more than a small business as a whole, increased the total earnings though the share of the manufacturing sector has reduced in 2013 from $9.6 \%$ to $9.5 \%$.

Financial indicators of small businesses in 2013 are shown in Table 2.

Table 2. Financial indicators of small businesses in 2013

\begin{tabular}{|l|c|c|}
\hline \multicolumn{1}{|c|}{ Indicator } & Small business & Micro business \\
\hline ROS, $\%$ & 5,3 & 5,1 \\
\hline ROA, $\%$ & 1,1 & 0,7 \\
\hline ROE (by operating profit), $\%$ & 7,7 & 5,4 \\
\hline Proportion of current assets, $\%$ & 49,05 & 46,88 \\
\hline Capital productivity, rub. / rub. & 0,39 & 0,15 \\
\hline Proportion of equity, \%, & 14,86 & 13,79 \\
\hline Assets turnover coefficient & 0,20 & 0,08 \\
\hline
\end{tabular}

Low rates of capital productivity and asset turnover could be regarded as evidence of inefficient use of assets or the presence of significant fixed assets not used in business processes, and not involved in the formation of financial results. [6] It can be also supposed that massive misreporting takes place. Obviously, the extremely low level of return on assets does not allow small business to use bank loans as a source for financing. Nevertheless, the share of debt in the amount of funding sources exceeds $80 \%$. Therefore, debt financial resources are the subject of the high risk, and small businesses have a high threat of bankruptcy.

\section{Conclusions}

By the results of the study it can be concluded that in now-day Russia small business does not perform the functions attributed to it by economic theory. Its contribution to innovation is modest. Its antimonopoly role does not fit the theoretical position. The role in job creation is noticeable but it is not accompanied by the role in income creation and by the appropriate indicators of business productivity. To get more objective and detailed picture the transparency of small business activity should be provided.To improve the situation the means should be originated both by the government and by entrepreneurs.

\section{References}

1. Small business step by step http://www.malb.ru/razvitie.html

2. Discussion of the research held by Public opinion fund dedicated to entrepreneurship in Russia on the radio Svoboda, Moscow. What hinders the development of small business in Russia? 2011.-http://ru.exrus.eu/Chto-meshayet-razvitiyu-malogo-biznesa-v-Rossiiid4e70d8236ccc19493c004907 
International Conference on Management, Business and Economics, Nov 2015

3. Keeble, D. New firm and regional economic development: Experience and impacts in the 1980s. Cambridge Regional Review, 1990, 1, p. 19-38.

4. Ketko N.V., Zarafutdinov R,R. Problems and prospects of development of small business in modern Russia // Russian Entrepreneurship. - 2011. - №9, vol. 1 (191). - p. 23-28. http://old.creativeconomy.ru/articles/13161/

5. Tarasevich, L.S., Grebennikov, P.I., Leussky, A.I. Microeconomics. - Moscow, 2006 - 374 p.

6. Bank, V.R., Bank, S.V., Taraskina, L.V. Financial analysis. - Moscow, 2006. -344 p. 